\title{
Tomasz M. Dąbek OSB, Modlić się Psalmami, Wydawnictwo Benedyktynów, Tyniec-Kraków, 2019, ss. 98
}

Księga Psalmów to jedna z najpopularniejszych i najchętniej czytanych ksiąg biblijnych. Już od ponad 2000 lat nad jej zapisami pochylają się zarówno Żydzi, jak i chrześcijanie - w tym katolicy, protestanci i prawosławni. Warto jednak podkreślić, że nie jest to łatwa księga. Powstała bowiem w obcej nam kulturze, w obcym nam języku (hebrajskim - biblijnym) i została napisana przez ludzi o innej mentalności niż nasza. Żeby zatem ją zrozumieć, potrzebna jest odpowiednia wiedza. Niestety, tę można zdobyć jedynie na wydziałach teologicznych. Wiadomo zaś, że nie wszyscy czytelnicy Pisma Świętego czują się powołani do tego, by studiować teologię. Wielu biblistów to rozumie i wychodząc naprzeciw ich oczekiwaniom, wydaje komentarze biblijne - w tym do Psałterza.

Jednym z tych egzegetów jest o. dr hab. Tomasz M. Dąbek OSB, Autor opiniowanej książki: Modlić się Psalmami, która nakładem Wydawnictwa Benedyktynów ukazała się w Tyńcu-Krakowie w 2019 roku. Już pobieżna lektura publikacji pozwala stwierdzić, że pisał ją z myślą o tym, by zaprezentować Psałterz jako „podręcznik” do modlitwy. Podzielił ją zaś na kilka passusów, które zatytułował: Wprowadzenie (s. 7-8), Psałterz jako modlitewnik Ludu Bożego Pierwszego Przymierza (s. 9-44), Psalmy w Nowym Testamencie (s. 45-58), Psatterz jako modlitewnik mnichów, osób konsekrowanych i duchownych (s. 59-68), Psatterz w liturgii i osobistej modlitwie chrześcijanina (s. 69-74), Myśli niektórych Psalmów (s. 75-94), Podsumowanie (s. 95-96) oraz Propozycje bibliograficzne (s. 97-98). Warto pokrótce je omówić.

We Wprowadzeniu (s. 7-8) o. dr hab. Tomasz Dąbek najpierw przypomniał, że II Sobór Watykański (1962-1965) na nowo odkrył piękno Księgi Psalmów. Podkreślił, że to właśnie Ojcowie Vaticanum Secundum zadecydowali, by do liturgii słowa - w formie śpiewów międzylekcyjnych — wprowadzić bardzo rozbudowane passusy z tej księgi. Następnie wyakcentował jeszcze, że w recenzowanej publikacji zamierzał jedynie ukazać rolę Psałterza w tradycji biblijnej i kościelnej, a nie stworzyć pełne kompendium na jego temat. 
Psałterz jako modlitewnik Ludu Bożego Pierwszego Przymierza (s. 9-44) to tytuł pierwszej zasadniczej części opiniowanej książki. We fragmencie tym Autor przytoczył najbardziej kluczowe dane na temat Księgi Psalmów. Odnotował między innymi, że oryginalną nazwą tej księgi jest תהלים (Tehilim). Wspomniał również, że twórcy Septuaginty (III-II w. przed Chr.), przekładając Biblię Hebrajską na język grecki, zastąpili tę nazwę słowem $\Psi \alpha \lambda \mu o r$ (Psalmoi), a Hieronim, autor Wulgaty (IV-V w. po Chr.) - mianem Liber Psalmorum. Następnie o. Dąbek nadmienił, że Psałterz, zanim powstał, przeszedł długą drogę od tradycji ustnej, sięgającej w wypadku niektórych psalmów nawet XII w. przed Chr., przez wstępne spisanie, które mogło się rozpocząć już w X w. przed Chr., aż po ostateczną redakcję, która najprawdopodobniej nastąpiła w IV w. przed Chr. Podczas dalszych analiz sporo uwagi poświęcił również autorstwu Psałterza. Udobitnił mianowicie, że z lektury Biblii Hebrajskiej wynika, że Dawid jest autorem 73 spośród 150 psalmów. Oczywiście przytoczył także imiona pozostałych współautorów Księgi Psalmów, między innymi: Salomona, Korachitów, Asafa czy Hemana. Jeszcze w tej części opiniowanej książki o. Dąbek wyakcentował także, iż Psałterz jest dziełem poetyckim. Przypomniał jednocześnie, że jedną z najważniejszych cech poezji biblijnej jest paralelizm członów. Dalej nadmienił, że paralelizm dzieli się na synonimiczny, antytetyczny, syntetyczny i klimaktyczny, po czym każdy z nich omówił. Wspomniał, że paralelizm synonimiczny zachodzi wówczas, gdy jakiś fragment dzieli się na dwie części i gdy myśl zawarta w pierwszej części, zostaje powtórzona w drugiej, ale za pomocą innych słów. Dla przykładu przytoczył zapis: dlaczego narody się buntuja, czemu ludy knuja daremne zamysty (Ps 2,1). Dalej wyjaśnił, że z paralelizmem antytetycznym mamy do czynienia wtedy, gdy jakaś perykopa dzieli się na dwa człony i gdy myśl zawarta w drugim członie jest przeciwstawiona myśli odnotowanej w pierwszym. Definicję tę zilustrował cytatem: bo Pan uznaje droge sprawiedliwych, a droga występnych zaginie (Ps 1,6). Następnie, wyjaśniając paralelizm syntetyczny, odnotował, że pojawia się on wówczas, gdy jakiś tekst składa się z dwóch części i gdy myśl zawarta w pierwszej części zostaje poszerzona i pogłębiona w drugiej. Opis ten uwieńczył wyjątkiem: podniosę kielich zbawienia $i$ wezwę imienia Pańskiego (Ps 116,13). I wreszcie wyjaśnił, że paralelizm klimaktyczny jest wtedy, gdy zapis kanoniczny składa się z dwóch albo więcej członów i gdy treść każdego kolejnego członu jest uzupełnieniem, pogłębieniem i rozjaśnieniem w stosunku do poprzedniego. Definicję tę zobrazował stychem: śpiewajcie Panu pieśń nowa, śpiewajcie Panu wszystkie krainy (Ps 96,1). Na koniec tego rozdziału o. Tomasz w zwięzły sposób przedstawił teologię Księgi Psalmów. Wyakcentował między innymi, że jej autorzy przedstawili Boga jako Stwórcę świata. Podkreślił również, że zaprezentowali Go jako kochającego i miłosiernego Pana oraz że ukazali Go jako sprawiedliwego Suwe-

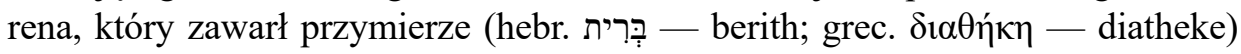
z Izraelem; zarówno ze wszystkimi Izraelitami razem, jak i z każdym z osobna. 
Drugi rozdział ocenianej publikacji Tomasz Dąbek zatytułował Psalmy w Nowym Testamencie (s. 45-58). We fragmencie tym podkreślił, że w zapisach nowotestamentowych pojawiają się liczne cytaty i odniesienia z i do Psałterza. Zaznaczył, że zachodzą one w tekstach Ewangelii, Dziejów Apostolskich i w literaturze epistolarnej. W tekstach Ewangelii, ponieważ jej redaktorzy zanotowali na przykład: rzekt Pan do pana mego: Siadź po prawicy mojej, aż położę Twoich nieprzyjaciót pod stopy Twoje (Mt 22,43-45 = Ps 110,1). Odnotowali również: Eloi, Eloi lema sabachthani, to znaczy: Boże mój, Boże mój czemuś mnie opuścit (Mk 15,34; Mt 27,46 = Ps 22,2). Z kolei w Dziejach Apostolskich, ponieważ Łukasz wspomniał w nich na przykład: niech opustoszeje dom jego i niech nikt w nim nie zamieszka! A urzad jego niech przejmie inny (Dz 1,20 = Ps 69,26; 109,8). Zacytował także: nie dozwolisz, aby Twój Święty ulegt rozkładowi (Dz 13,35 = Ps 16,10). I wreszcie w literaturze epistolarnej, ponieważ pojawiają się w niej takie wyjątki pochodzące z Psałterza jak na przykład: błogosławieni ci, których nieprawości zostały odpuszczone i których grzechy zostały zakryte. Blogostawiony mąz, któremu Pan nie liczy grzechu (Rz 4,7-8 = Ps 32,1-2); dziś, jeśli głos Jego styszycie, nie zatwardzajcie serc waszych (Hbr 4,7 = Ps 95,7-8). W trakcie dalszych analiz Autor opiniowanej publikacji nadmienił jeszcze, że Księga Psalmów cieszyła się wielką popularnością zarówno w czasach Starego, jak i Nowego Testamentu.

Trzecia część recenzowanej książki nosi tytuł Psałterz jako modlitewnik mnichów, osób konsekrowanych i duchownych (s. 59-68). W urywku tym Autor odnotował między innymi, że już od III-IV wieku Psałterz zaczął stawać się podstawowym modlitewnikiem mnichów - najpierw wschodnich, potem zachodnich. Dodał przy tym, że pierwotnie mnisi, modląc się, odczytywali bądź odśpiewywali Księgę Psalmów w kolejności kanonicznej. Udobitnił także, że z czasem zaczęli zmieniać kolejność Psalmów tak, by lepiej korespondowały z porą dnia, w której je odmawiano. Następnie uwydatnił, że pierwotnie — na potrzeby modlitwy wspólnotowej - Psałterz dzielono tak, aby odmówić go (bądź odśpiewać) w ciągu jednego tygodnia. Wyakcentował również, że stopniowo zaczęto go dzielić nie tylko na jeden, lecz także na dwa bądź cztery tygodnie. W toku dalszych analiz zauważył jeszcze, że mnisi benedyktyńscy w Polsce korzystają z dwutygodniowego podziału Psałterza.

Kolejny, czwarty rozdział opiniowanej książki Autor zatytułował Psatterz w liturgii i osobistej modlitwie chrześcijanina (s. 69-74). W passusie tym przytoczył między innymi opinię Atanazego (IV w. po Chr.) na temat Księgi Psalmów. Wspomniał mianowicie, że Psałterz to „mała Biblia” zawierająca najbardziej kluczowe wiadomości na temat Boga i człowieka. Nadmienił także, że to „Zwierciadło", w którym można dostrzec swoje wady i zalety. W toku dalszych analiz uwydatnił również, że w minionych wiekach Psałterz był bardzo popularny zarówno w wersji łacińskiej, jak i w wydaniach przełożonych na ojczyste języki chrześcijan. Przy tej okazji odnotował także, że w Polsce największą popular- 
nością cieszyły się: Psałterz Floriański (XVI w.), Psałterz Puławski (XVI w.) i Psałterz w thumaczeniu Jana Kochanowskiego (XVI w.). Rozdział ten o. Dąbek uwieńczył cytatem pochodzącym z „Konstytucji o Liturgii Świętej” II Soboru Watykańskiego, w którym Ojcowie Vaticanum Secundum zachęcali świeckich do odmawiania brewiarza (KL 100), przebogatego w cytaty z Psałterza.

Piąty, ostatni rozdział recenzowanej książki o. dr hab. Tomasz Dąbek opatrzył tytułem Myśli niektórych Psalmów (s. 75-94). W passusie tym w syntetyczny sposób zaprezentował kilka psalmów, między innymi 3 i 150. Analizując Psalm 3, przypomniał, że Biblia Tysiąclecia zatytułowała go „Modlitwą prześladowanego". Nadmienił także, że tradycje żydowska i chrześcijańska dopatrują się jego autora w królu Dawidzie. Wspomniał również, że powstanie tego psalmu związane jest z buntem Absaloma - syna Dawida - kiedy to król najpierw musiał uciekać przed swoim potomkiem, a następnie zbrojnie przeciwko niemu wystąpić. Podczas dalszych analiz o. Dąbek udobitnił jeszcze, że zapis ten jest najpierw wielkim krzykiem rozpaczy z powodu cierpień zadawanych przez najbliższych, w tym przez rodzinę, a następnie aktem wiary, że Bóg jest silniejszy od każdego zła, w tym tego czynionego przez bliskich i krewnych. Z kolei omawiając Psalm 150, Autor opiniowanej książki uwypuklił między innymi, że rozpoczyna się on i kończy tym samym słowem, a mianowicie Alleluja. Wyjaśnił również, że wyraz ten jest wezwaniem do oddawania czci Bogu, który objawił się Mojżeszowi. Podkreślił także, że jest on zachętą do składania uwielbienia Panu, który jest bezkresnym, niekończącym się Istnieniem i Obecnością (= Jestem, któ-

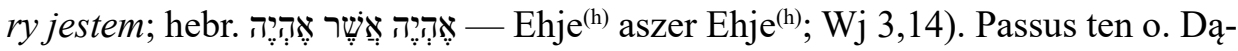
bek uwieńczył puentą, że Psalm 150 to jedna wielka doksologia na cześć Jahwe.

W Podsumowaniu (s. 95-96) Autor recenzowanej książki uwydatnił między innymi, że Psałterz jest perłą literatury religijnej i światowej. Zaznaczył, że jest on utworem, po który regularnie powinni sięgać zarówno Żydzi, jak i chrześcijanie, wierzący i niewierzący. Jest on bowiem dziełem, które potrafi przemienić serca swoich czytelników.

W ostatniej części książki, a mianowicie w Propozycjach bibliograficznych (s. 97-98) Tomasz Dąbek wyszczególnił kilka podstawowych publikacji na temat Psałterza. Wymienił na przykład: Modlitwę Biblia Józefa Kudasiewicza, Teologię Psalmów Antoniego Troniny czy też Psalmy - dialog z Bogiem Henryka Witczyka.

Kończąc niniejszą recenzję, należy stwierdzić, że opiniowana książka — Modlić się Psalmami — to nietuzinkowa publikacja; jej Autor zaś — o. dr hab. Tomasz M. Dąbek OSB — to rozmodlony i rozkochany w Księdze Psalmów mnich, doskonały biblista umiejętnie łączący modlitwę z pracą naukową i wreszcie wyśmienity pisarz, wybornie władający piórem, piszący językiem jasnym, zwięzłym i prostym. Nie pozostaje już nic innego, jak tylko zachęcić do lektury jego 
książki. A polecić ją można zarówno specjalistom (teologom, biblistom), jak i niespecjalistom (zwykłym czytelnikom Biblii).

\author{
Jarosław Ćwikła ${ }^{1}$ \\ Prymasowski Instytut Kultury Chrześcijańskiej w Bydgoszczy, Polska
}

\begin{abstract}
The Book of Psalms is one of the most popular and most read Bible books. For over 2,000 years, both Jews and Christians — including Catholics, Protestants and Orthodox Christians — have been reading it. It is worth emphasizing, however, that this is not an easy book. It was created in a culture foreign to us, in a foreign language (Hebrew — biblical) — it was written by people with a different mentality than ours. Therefor to understand it, you need the right knowledge. Unfortunately, this can only be obtained at theological faculties. It is known, however, that not all Bible readers feel called to study theology. Many exegetes understand this and write comments for them on Bible books, including the Book of Psalms.

One of these exegetes is Fr. professor Tomasz M. Dąbek, the author of the book: To pray with Psalms, which was published in 2019 in Tyniec-Krakow. He divided his dissertation into several parts, which he titled: Introduction (pp. 7-8), Psalter as a prayer book of the People of God of the First Covenant (pp. 9-44), Psalms in the New Testament (pp. 45-58), Psalter as a prayer book to monks, consecrated persons and clergy (pp. 59-68), Psalter in the liturgy and in the personal prayer of a Christian (pp. 69-74), Thoughts about some Psalms (pp. 75-94), Summary (pp. 95-96) and Bibliographic proposals (pp. 97-98).
\end{abstract}

This review presents his book.

\title{
Keywords
}

Bible, Book of Psalms, prayer book, monk, nun, worshipers of the Psalter

\section{Słowa kluczowe}

Biblia, Księga Psalmów, modlitewnik, mnich, zakonnica, miłośnicy Psałterza

1 Jarosław Ćwikła, dr - biblical theologian, graduate of the Primate’s Institute of Christian Culture in Bydgoszcz (1989-1994), Postgraduate Theological Studies at the Faculty of Theology at Adam Mickiewicz University in Poznań (1997-2001) and Postgraduate Pedagogical Studies for Theologians also at the Faculty of Theology of the Adam Mickiewicz University in Poznań (2004-2005). Since 2011, he has been teaching biblical studies at the Primate's Institute of Christian Culture in Bydgoszcz (until 2015 - classes; from 2015 - lectures). Since 2013, he belongs to the Association of Polish Biblists; e-mail: drjaroslaw.cwikla@gmail.com. ORCID: 0000-0002-4325-1462. 